\title{
Implementing a quattromodal freight hub: an approach for the city of Vienna
}

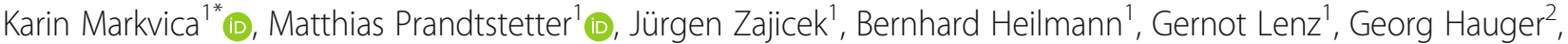 \\ Monika Wanjek ${ }^{2}$, Claudia Berkowitsch², Sarah Pfoser ${ }^{3}$, Oliver Schauer ${ }^{3}$, Lisa-Maria Putz ${ }^{3}$, Reinhold Schodl ${ }^{4}$ and \\ Sandra Eitler ${ }^{4}$
}

\begin{abstract}
Purpose: In terms of freight transportation it is essential to pick the most convenient mode(s) of transport (MOT). To get a more flexible system, one can assume that the number of transport options at each hub should be maximized. Therefore, it is investigated how a new hub concept comprising four MOT, a so-called "quattromodal freight hub", can be implemented in the existing transport system from a traffic planning, technological and organizational point of view.

Methods: The research incorporates screening existing literature and best practices, conducting stakeholder interviews as well as performing site visits at the best practice areas Hamburg (Germany) and Constanta (Romania). Furthermore, the implementation perspective for a quattromodal freight hub in the city of Vienna (Austria) is examined.

Results: The research revealed the strengths, weaknesses, opportunities and threats of the concept from a theoretical and practical perspective. Four options to create a quattromodal freight hub in the city of Vienna could be identified taking the effects on the overall transport system capacity, arising costs and the legal framework into account.

Conclusions: Cost and efficiency related decision criteria are decisive for the implementation of a quattromodal freight hub. An implementation in the city of Vienna is attractive in terms of prestige and unique selling proposition for the region but at the same time requires further research in terms of legal aspects and impacts on the region.
\end{abstract}

Keywords: Freight transportation, Freight logistics, Hubs, Quattromodality, Quattromodal freight hub, Vienna region

\section{Introduction}

In December 2008, the European Commission (EC) agreed upon a package of directives and targets for climate protection and energy ("20-20-20 targets"). One of the targets for the year 2020 addresses the reduction of greenhouse gas emissions by $20 \%$ compared to the year 2005 [1]. Other important steps in this direction were the Paris Agreement in 2015 [2] and the Katowice Climate Package 2018 [3] as a global agreement implementing the Paris Agreement. Since the transport sector is a key factor for the achievement of these objectives, the EC has set the objective to shift 50\% of transports in the European Union over $300 \mathrm{~km}$ to environmentally friendly transports (such as rail and inland navigation)

\footnotetext{
* Correspondence: karin.markvica@ait.ac.at

'AIT Austrian Institute of Technology, Center for Mobility Systems, Giefinggasse 4, 1210 Vienna, Austria

Full list of author information is available at the end of the article
}

by 2050 to reduce $\mathrm{CO}_{2}$ emissions and further negative impacts on the environment [4].

In alignment with these goals the concept of the Physical Internet (PI) [5] emerged in the logistics sector. Here, the main idea is to enhance efficiency by vertical and especially horizontal collaboration and cooperation among all stakeholders and competitors along the supply chain. However, to be more responsive to user requests the PI idea contains also strategies related to (intermediate) warehouse placements [6]. One of the initiatives within the PI is the transition of the current (partly intermodal freight) transportation network towards a synchromodal transportation network [7] as outlined in the ALICE roadmaps towards the PI [8]. Synchromodality, also referred to as Transport-as-a-Service in some contexts, is the continued development of intermodal and multimodal transport systems, whereby the actors along the transport chain cooperate and goods can switch in real-time between the modes of transport (MOT) in the most 
flexible way adapted to the respective resources [9]. Only the most basic transport requirements, such as costs, duration or sustainability requirements are defined by the consignor in advance to optimize transport and utilize existing resources best possible [7]. Hence, synchromodality refers to a transport concept which aims at shifting traffic from road to environmentally friendly MOT, such as rail and navigation while keeping flexibility of road transports.

Relevant publications on multimodality in freight transport such as the "Green Paper on Sustainable Logistics" [10] and the "Green Paper on Sustainable Logistics in Urban Areas" [11] focus on offering more than one MOT for freight transport at a location but are nonetheless currently limited to bi- or trimodal transport incorporating road, rail and/or inland navigation only. However, air cargo is dealt with in terms of the Trans-European Airport network but apart from that left out in most papers on multimodal transportation. To be able to pick the most convenient MOT, variety at a transshipment point is a crucial factor.

As passenger numbers tend to increase and are expected to reach 7 billion persons by the year 2034 according to the International Air Transport Association [12], air traffic is going to expand which offers capacity for transport of goods. The air industry agreed on targets to reduce environmental damage [12]. Therefore, air cargo is expected to be more environmentally friendly in the future and hence more competitive compared with other MOT. As a further logical step, an integration of air cargo in the existing hub structure would be desirable. Taking traffic planning as well as organizational and technological matters into account is one step in the process. The main research question is therefore: "Is it possible to create something bigger, like a quattromodal freight hub, out of an existing infrastructure?"

Quattromodal transport offering four different MOT is rarely discussed even though some studies [13, 14] already deal with possible models and effects of a regional and/or organizational linkage of several MOT taking into account air cargo and giving practical examples. Furthermore, there are hardly any hubs which are characterized by an integration of air cargo into freight transport and already integrated in an optimal manner in the freight network in terms of transport technology and/or organization. The technical and/or organizational integration of air cargo in the freight transport network is currently taking place at the largest airports in Europe. Only a few European cities (e.g. Hamburg) are a quattromodal transport provider for freight transport so far.

Since the concept of quattromodality is only slightly targeted by research, an exhaustive literature review only revealed partially useful definitions mainly pointing out the opportunity to use different MOT at a location and to link them together [15]. For this research, quattromodal hubs were therefore defined as "logistics pivots where the four MOT road, rail, waterways and air cargo come together" [16]. Pipelines as transport mode as well as the distinctions between inland and maritime navigation and regular and broad gauge suggested by Kummer [15] are deliberately left out to make the definition more readable and easier to comprehend for non-specialists [17].

Due to areal constraints (limited space), the potential of such a quattromodal freight hub offering four different MOT has to be assessed in a regional context. Beyond that, its practical relevance for freight transportation has to be investigated to reveal ecological, economic and social effects deriving from a new hub concept and to legitimate additional costs that might derive from it. Therefore, the question "How to establish a quattromodal freight hub in a region with potential?" should be addressed.

Details on the methodology are given in Chapter 2. Information on the site visit locations and key findings from the expert interviews can be found in Chapter 3 . Chapter 4 examines the implementation perspective for a quattromodal freight hub in City of Vienna (Austria) and deals with the impact on the overall transport network. Chapter 5 outlines the conclusions and the discussion of the findings and further research needed.

\section{Methodology}

The concept of quattromodality is not only in an early development stage from a theoretical point of view, but also from a practical one. Because of the lacking practical implementation, there are no reliable empirical values, figures and facts available for existing approaches. To generate knowledge on potential offered by quattromodality for the City of Vienna, our research focused on knowledge carriers as well as best practice hubs.

The research revolving around the two main questions "Is it possible to create something bigger out of an existing infrastructure?" and "How to establish a quattromodal freight hub in a region with potential?" therefore concentrated on

1) Desk research on

a. quattromodality and quattromodal freight hubs

b. best practice examples in Europe and beyond (including telephone enquiry)

c. specifications (technical, economical etc.) of various transport modes

d. framework conditions for an implementation in Vienna

2) Qualitative and quantitative data collection via

a. site visits to best practice areas Hamburg (March 2016) and Constanta (May 2016) 
Table 1 Site visits

\begin{tabular}{|c|c|c|c|c|c|c|c|}
\hline Location & Road & Rail & $\begin{array}{l}\text { Inland } \\
\text { navigation }\end{array}$ & $\begin{array}{l}\text { Maritime } \\
\text { navigation }\end{array}$ & $\begin{array}{l}\text { Air } \\
\text { cargo }\end{array}$ & Pipeline & Description \\
\hline Hamburg & $x$ & $x$ & $x$ & $x$ & $x$ & $x$ & $\begin{array}{l}\text { Four modes of transport are used by logistics providers, which is why there are } \\
\text { various branches (e.g. at the airport, at the port and at a rail junction). Not all } \\
\text { transport modes are interconnected at the moment. }\end{array}$ \\
\hline Liège & $x$ & $x$ & $x$ & & $x$ & & $\begin{array}{l}\text { Focus on the airport on cargo, not on passengers. Intensive efforts to integrate rail } \\
\text { into air freight. Europe's third largest inland port. }\end{array}$ \\
\hline Constanta & $x$ & $x$ & $x$ & $x$ & $x$ & $x$ & $\begin{array}{l}\text { Pentamodal connections are advertised on homepage, but airport is not used for } \\
\text { cargo. Transport activities carried out by private operators, port itself cannot make } \\
\text { any statements. }\end{array}$ \\
\hline Galati & $x$ & $x$ & $x$ & & & & River, sea, road, railway (European and Russian gauge) but no airport. \\
\hline $\begin{array}{l}\text { Rhein- } \\
\text { Ruhr area }\end{array}$ & $x$ & $x$ & $x$ & & $x$ & $\mathrm{x}$ & $\begin{array}{l}\text { There is a connection from Duisport to Düsseldorf Airport, but it is very rarely used, } \\
\text { air freight is only a niche business. Port of Cologne only trimodal. Generally no } \\
\text { train connection to the airport in Cologne. No connection between port and } \\
\text { airport. }\end{array}$ \\
\hline Dubai & $x$ & & & $x$ & $x$ & $x$ & $\begin{array}{l}\text { Dubai generally has no railway. Al Maktoum International (DWC) is a cargo airport } \\
\text { near the port (sea-air connection). LDL Top Most Freight Solutions "offer air, sea, } \\
\text { rail or overland under the responsibility of a single transport operator". }\end{array}$ \\
\hline Busan & $x$ & $x$ & $x$ & $x$ & $x$ & $x$ & Airport 17 km from the port, but aircraft is not used. Railway already used. \\
\hline Cuxhaven & $x$ & $x$ & & $x$ & $x$ & $x$ & "Cuxhaven Sea-Airport" marketing name but not multimodal. \\
\hline Barcelona & $x$ & & $x$ & $x$ & $x$ & $x$ & Road, port and airport but no rail connection. \\
\hline
\end{tabular}

b. interviews with experts at the best practice areas Hamburg and Constanta based on guiding questions (see Additional file 1) to diagnose the state of the implementation (March 2016)

c. interviews with (inter-)national experts based on a standardized interview guideline (see Additional file 2) to assess the potential for Vienna (December 2015 until May 2016)

3) Scenario assessment/forecasting techniques for the impact estimation of such systems on transport in Vienna

In terms of site visits, Hamburg, Liège and Constanta were identified as especially interesting not only due to their importance for freight logistics but also due to the range of freight related organizations located there (cf. Table 1). Since scheduling stakeholders for an interview failed for Liège, the site visits were performed in Hamburg and Constanta.

Employees from 23 organizations participated in the interviews (see Table 2) which were conducted between December 2015 and May 2016. Except for three interviews via phone, all interviews were face-to-face interviews. Nine interviews were conducted during site visits to Hamburg and Constanta based on an interview guideline (see Additional file 2), all other interviews were performed in Austria based on guiding questions (see Additional file 1).

The insights on the practical implementation from best practices site visits and the expert point of view on the potential arising from quattromodality not only resulted in a SWOT analysis which is explained in detail in [18] but also in a conceptualization of the implementation of a quattromodal freight hub for the City of Vienna. This conceptualization not only included practicability, technical aspects and costs but also the effect on the overall transport system.

\section{Site visits and expert interviews}

In this section, details on the site visit locations and results of the expert interviews in Hamburg, Constanta and Austria are given. A more detailed representation of the interview results can be found in [18].

\subsection{Hamburg site visit}

The city of Hamburg in Germany has an area of 755.1 sq. km [19] and around 1.83 mio. Inhabitants in 2018 [20]. In the metropolitan region of Hamburg, the logistics sector directly or indirectly accounted for around 250,000 jobs in 2010 [21].

Hamburg offers road, rail, navigation, aviation and pipeline. The airport occupies an area of $5.7 \mathrm{sq} . \mathrm{km}$ [19] and had 17.6 mio. Passengers and 74,948 tons air freight in 2017 [22]. Nevertheless, the port is decisive for the handling of goods. Road freight transport benefits enormously from the volume of shipping transported. According to the industry portrait "Freight traffic in Hamburg" (2010) only about a third of the containers handled in the port of Hamburg had their destination or origin in the metropolitan region [21]. Around half of the containerized goods were either processed there or were destined for further transport via distribution centers. Due to the comparatively short distances $80 \%$ to 
Table 2 Stakeholderinterviews

\begin{tabular}{|c|c|c|c|}
\hline Interview conduction & Date & Interview partner & Role \\
\hline face-to-face interview & $9 / 12 / 2015$ & Austrian waterway operator & infrastructure manager \\
\hline phone interview & $11 / 1 / 2016$ & Quehenberger Logistics & service provider \\
\hline face-to-face interview & $12 / 1 / 2016$ & Fraunhofer Austria & research \\
\hline face-to-face interview & 20/1/2016 & ACS Logistics & service provider \\
\hline face-to-face interview & $21 / 1 / 2016$ & Air Cargo Center Airport Hörsching & service provider \\
\hline face-to-face interview & 25/1/2016 & Port of Linz & infrastructure manager \\
\hline face-to-face interview & $25 / 2 / 2016$ & Vienna University of Economics and Business & research \\
\hline phone interview & $25 / 2 / 2016$ & Vienna International Airport & infrastructure manager \\
\hline face-to-face interview & 29/2/2016 & Port of Hamburg Marketing e.V & infrastructure manager \\
\hline face-to-face interview & $2 / 3 / 2016$ & Port of Vienna & infrastructure manager \\
\hline face-to-face interview & $3 / 3 / 2016$ & Container Terminal Ennshafen & politics \\
\hline face-to-face interview & $7 / 3 / 2016$ & Lufthansa Cargo & service provider \\
\hline face-to-face interview & $16 / 3 / 2016$ & KLU Kühne Logistics University & research \\
\hline face-to-face interview & $16 / 3 / 2016$ & TUHH Hamburg University of Technology & research \\
\hline face-to-face interview & $17 / 3 / 2016$ & HPA Hamburg Port Authority & infrastructure manager \\
\hline face-to-face interview & $17 / 3 / 2016$ & Kühne+Nagel & service provider \\
\hline face-to-face interview & $18 / 3 / 2016$ & DAKOSY Datenkommunikationssystem AG & service provider \\
\hline face-to-face interview & $18 / 3 / 2016$ & LHU Luft-Hafen-Umschlag GmbH \& Co. KG & service provider \\
\hline phone interview & 23/3/2016 & Cargo Center Graz & service provider \\
\hline face-to-face interview & $4 / 5 / 2016$ & City of Vienna - MA 18 & politics \\
\hline face-to-face interview & $25 / 5 / 2016$ & Maritime Ports Administration Constantza & infrastructure manager \\
\hline face-to-face interview & $26 / 5 / 2016$ & Asociatia Romana de Logistica & politics \\
\hline face-to-face interview & $26 / 5 / 2016$ & DB Schenker & service provider \\
\hline
\end{tabular}

$90 \%$ of these collection and delivery journeys were handled via trucks [21].

Hamburg port stretches on an area of $72 \mathrm{sq} . \mathrm{km}$ [19]. Measured by container turnover, Hamburg port is the third largest port in Europe in 2017 with 8.82 mio. TEU [23]. The seaborne cargo handling at that time was 136.5 mio. Tons mainly concentrating on container (90.3 mio. tons) and grab cargo (23.5 mio. tons), followed by liquid cargo (13.7 mio. tons), agribulk (7.5 mio. tons) and break bulk (1.4 mio. tons) [23]. The modal split in container traffic was $56.6 \%$ truck, $41.4 \%$ rail and $2 \%$ barge. The port railway is the link between the transshipment terminals of the container ships and the European rail network with 46 tons cargo handling a year.

\subsection{Constanta site visit}

Constanta is located in south-east Romania and has a size of $58 \mathrm{sq} . \mathrm{km}$ with a population of around 300,000 inhabitants [24]. It is the only Romanian city served by road, rail, sea, river and air, and therefore among the most important cities of Romania due to its economic importance and activities in logistics [25]. At the same time, not all of these MOT are interconnected and therefore intermodality/multimodality is limited.
Constanta has the biggest port on the Black Sea which is one of the major European ports [25]. 413,253 containers and 670,536 TEUs were handled in 2017 [26]. The port offers access to the European railway network from every terminal through a $300 \mathrm{~km}$ railway system [26]. In 2017, a Memorandum of Cooperation with Romanian state rail cargo operator CFR Marfa and the Port of Constanta Authority was signed by the freight forwarder PKP Cargo and the Port of Gdansk Authority. This was done to enhance the logistics services on the railway corridor between the two ports Gdansk (Poland) and Constanta [27].

The Mihail Kogalniceanu International airport is in $25 \mathrm{~km}$ distance from the city and serves as the main airport [25] which is primarily used for passenger transport. The freight terminal was constructed a few years ago and has a capacity of 2500 cubic meters [28].

\subsection{Results from expert interviews}

To develop a baseline for the case study, the most important interview results are summarized. Certain aspects, pointed out by the experts, are emphasized since they influence a successful linkage of the existing infrastructure. Current shortcomings of the site visit 
locations are stated to give insights on the implementation potential in these regions.

\subsubsection{Spatial, technological and organizational aspects}

The stakeholder interviews with experts from Austria and neighboring countries showed that the term "quattromodal hub" is not entirely self-explanatory, i.e. it requires a clear definition.

The spatial proximity of the modes of transport is generally regarded as important, with respondents considering a quattromodal hub to be more spacious and not bundled to one location. In a previous question it was already pointed out that aviation takes up a lot of space and therefore requires spatial expansion. Two interviewees remarked that shipping and aviation are not compatible and therefore do not make sense at one location.

The uneven picture in terms of spatial distance is conclusive based on different perspectives: For logistics service providers, spatial distances are part of the business basis, while spatial bundling tends to bring advantages for infrastructure operators.

Only a few interviewees regard a technical coordination as little or not important. In this context, technological differences between the airport and container terminals as well as the low level of networking between the airport and the outside world are referred to. The other participants regard it as a very important, if not a basic prerequisite. In this context, reference is made to the importance of compatible containers and security aspects.

Two interviewees consider the organizational coordination to be of little importance, the other interviewees consider the organizational coordination to be important or very important. Here it is pointed out that this is in any case closely linked to technological coordination.

\subsubsection{Potential assessment and SWOT}

More than one interviewee emphasized the feasibility or practical relevance of a quattromodal hub. It was also mentioned that the definition should be as broad as possible. It was further mentioned that unused potentials of trimodal hubs should serve as a starting point and different regional understanding (thus also the role of pipelines) should be considered.

Regarding the SWOT (strengths, weaknesses, opportunities and threats) arising from a quattromodal freight hub, various aspects were mentioned by the experts. The technological differences between the airport and container terminals, carrier incompatibility, safety and IT aspects were mentioned as hindering factors at current freight hubs due to the lack in standardization. In case of the IT related aspects, the concerns were later on overcome by an expert in the data communication domain. Furthermore, the low level of transport network integration of airports was detected as a problem. The potential resistance of the population or residents and conflicts of interest between different stakeholders were pointed out as main weaknesses of the concept of quattromodality. Even though these concerns exist, more than two thirds of the experts interviewed ascribe a quattromodal freight hub efficiency potential in either ecological or economical regard. Most interview partners agreed with the USP a quattromodal freight hub offers and the potential for easier handling of the most appropriate MOT. A rather neutral attitude was shown towards the spatial proximity. This was reasoned by the low transport costs between MOT that distance is not a relevant factor in terms of connecting air cargo to other transport modes.

\subsubsection{Implementation potential for site visits}

On closer examination of best practice regions, the experts in Hamburg revealed that the combination of air cargo and navigation is currently used for certain categories of goods such as luxury items, repair parts, (economically) perishable and other time-sensitive goods as well as medicines and drugs pointing out the lack of a shared storage space at the site. Regarding the inclusion of air cargo, the transport volume was stressed as one limiting factor since a combination must be efficient and the cost-benefit-ratio has to support the decision. The interview partners in Constanta were less concerned about the concept itself and more focused on the lacking implementation perspective at the site due to various limitations such as the current military use of the airport. Therefore, they agreed with the value of a quattromodal freight hub as new business concept for the location but revealed that Constanta would not be able to manage such a freight hub soon.

\section{Application for the City of Vienna}

In Austria, the transport sector accounts for almost a quarter of greenhouse gas emissions [29], which can (apart from passenger transport) lead back to its importance as a logistic base. The high logistics competence of Austria is emphasized both by the "International Business Compass 2014" and the Hamburg Institute of International Economics. The World Economic Forum places the location among the top 10 with the quality of rank 6 for roads and rank 12 for railway [30]. For the year 2011, the Austrian motorway network density was $20.5 \mathrm{~km}$ per 1000 sq. km (compared to $16.3 \mathrm{~km}$ per $1000 \mathrm{sq} . \mathrm{km}$ in the EU average) and the Austrian railroad density with $58.3 \mathrm{~km}$ per 1000 sq. $\mathrm{km}$ (compared to $49.2 \mathrm{~km}$ per 1000 sq. $\mathrm{km}$ in the EU average) [31].

Compared to other European countries, the Austrian infrastructure is well developed. This also accounts for the City of Vienna where the port of Vienna functions as a 
trimodal hub covering rail, road and navigation and at approximately $9.5 \mathrm{~km}$ air-line distance the Vienna International Airport operates as a bimodal freight hub covering road and air cargo; not including rail as freight transport option due to a lack of freight rail tracks. Both hubs are located at the western bank of the Danube River with direct access in the case of the port of Vienna and a $3 \mathrm{~km}$ air-line distance for the Vienna International Airport, see also Fig. 1.

To create in quattromodal freight hub in Vienna, the port of Vienna and the Vienna International Airport have to be connected to each other since there are no other locations providing adequate air cargo and inland navigation qualities. This requires a well elaborated connection between these two sites. Considering the geographic location and existing transport system, we identified four different options to connect the Vienna International Airport to the port of Vienna to operate freight transport:

1. Connection via road

2. Connection via rail

3. Connection via circulating cable car and inland navigation

4. Connection via freight-zeppelin

\subsection{Connection via road}

Among all four options, the connection via road between the port of Vienna and the Vienna International Airport is




the only existing one. It includes A4 Ost Autobahn (East Highway), B228 Simmeringer Straße (Simmeringer Road) and B14 Klosterneuburger Straße (Klosterneuburger Road) (Fig. 1). The terminal at the port of Vienna as well as the cargo center at the Vienna International Airport have road access and are therefore well connected via the road network.

Since this is an existing transport connection, this solution does not involve additional costs apart from infrastructure maintenance costs in the case of increased traffic volume. However, a barrier of implementation could be the environmental aspect and the associated image for the City of Vienna on the one side and the current traffic levels at this highway section on the other side. To evaluate the connection between the two locations, an estimation of the effects of additional trucks on travel times on this route was assessed (see Chapter 4.5).

\subsection{Connection via rail}

The Vienna International Airport has currently three terminals, an office park, a General Aviation Center/VIP Terminal and an air cargo center. To deal with the growing demand for international air traffic and to maintain the position of Vienna as an attractive and competitive passenger and freight hub within Europe, expansion blueprints for the Vienna International Airport were introduced. The airport management strives for a third runway which will be $3680 \mathrm{~m}$ long and $60 \mathrm{~m}$ wide and constructed until the year 2025 [32]. As a result of the citizens' participation process in order to achieve minimized noise pollutions, it shall run $2400 \mathrm{~m}$ south of the first runway (runway 29/11) and parallel to it which means that the B10 Bruckner Bundesstraße (Bruckner Federal Road) has to be relocated further to the south. Nowadays, no further changes to the existing infrastructure are known to public but the possibility is given due to major improvements. Therefore, we did not take the current location of the cargo center as a limiting factor for the rail concept.

In contrast to the surrounding companies, the Vienna International Airport mainly focusses on passenger transport and is not connected to the rail network via freight rail tracks. The port of Vienna on the other hand has freight rail tracks in use and therefore already enjoys better transportation connections. To connect the airport to the rail network it is necessary to dock on the freight rail tracks of the Petrochemie Danubia northwest of the Vienna International Airport. This not only requires the new installation of a $4 \mathrm{~km}$ section but also the relocation of the air cargo center between the current airfield and the planned extension (Fig. 2).

The existing rail network furthermore does not offer a straight connection between the port of Vienna and the Vienna International Airport. A connection without

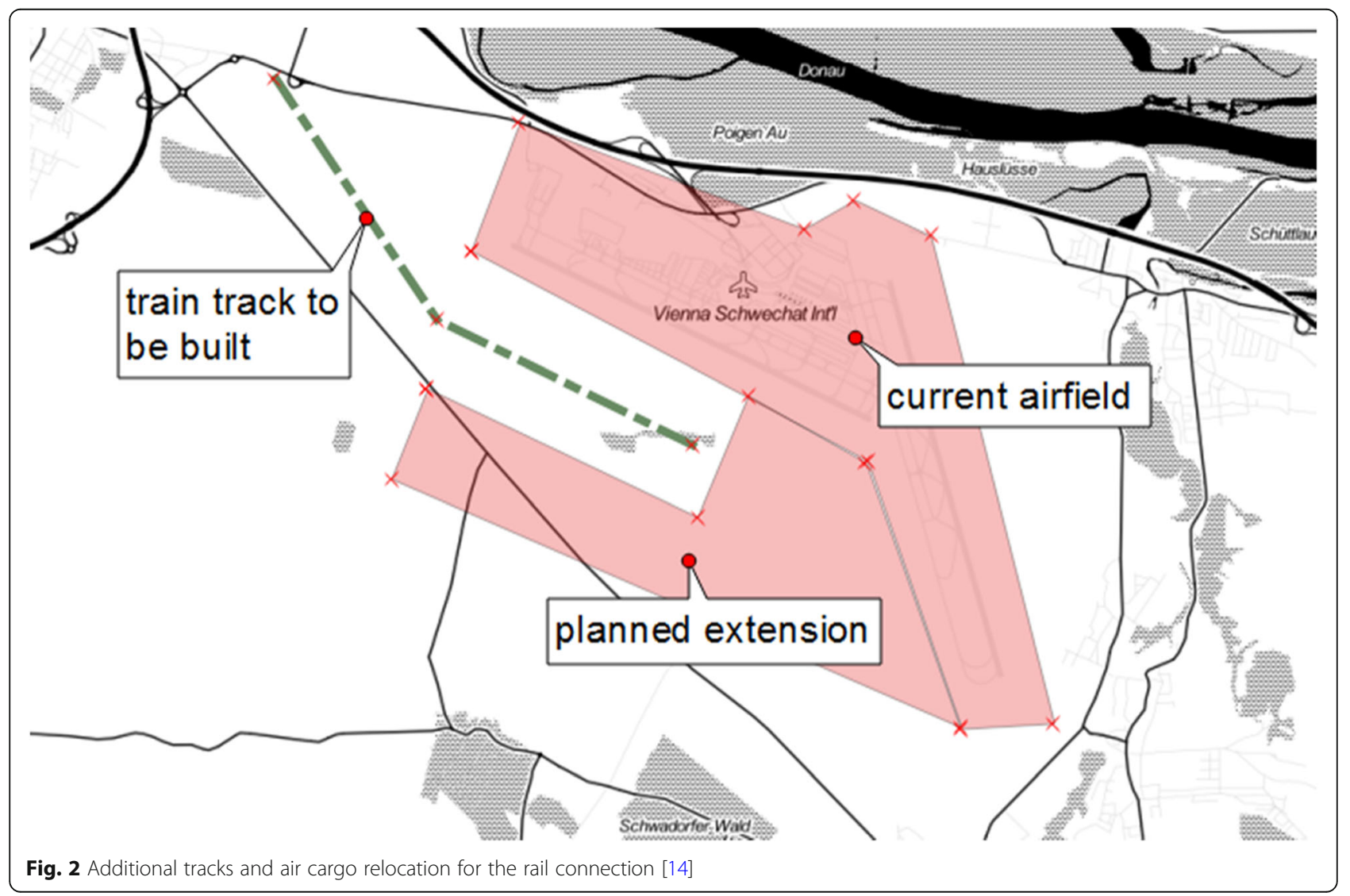


detours would require using the station Kaiserebersdorf as connection point between the tracks from the port of Vienna and the Vienna International Airport. The second option would be to accept a detour and use the loop via Kledering - Hauptbahnhof (Vienna Central Station) - Meidling - Donaulaendebahn - Kaiserebersdorf (see also Fig. 3) which would be the more cost-efficient solution since the installation of a skidway is more expensive than the additional travel time. Besides costs, the detour has the additional advantage that is offers a direct connection to the new freight yard Inzersdorf which went into full operation in the year 2017 and the skidway Kledering offering the routing of wagon groups in the direction of international destinations.

Apart from using the rail network most efficiently, the air cargo center has to be designed taking certain requirements into account. Since the freight rail track mark an end at the air cargo center, a terminal station would result. At least three tracks should be envisaged to transform it to a skidway of which two tracks are available for unloading and loading the trains. An essential part of the track system is that the design allows the arriving trains to enter the hall by means of the line locomotive. The line locomotive is consequently separated from the train and can use the loop around the hall to move from one end to the other. This does not require a lot of personnel since only a specially trained person is needed to interlock and perform the brake test.

\subsection{Connection via circulating cable car and inland navigation}

Another alternative to connect the two freight hubs is based on the consideration that the hardly used Danube River is nearby the airport and would provide a direct connection to the port of Vienna without disturbance of the existing transport network. A hindering factor in this regard is the Danube-Auen nature reserve which is located north of the airport. A direct connection via road or tunnel is therefore not possible.

An alternative approach would be to use the air space and therefore a circulating cable car which connects the riverbank to the air cargo center in $1.5 \mathrm{~km}$ distance (Fig. 4). The pillars of the cable car do not lead to dissection of the landscape and do not require much space on such a short distance. As a transshipment area to load the goods on the barge, an area with agricultural use on the Danube River could be considered.

Apart from the already introduced advantages, the cable car can be automated. With a minimum additional staff, it is a very efficient way to transport goods from one place to another [33]. To use a circulating cable car would mean that this infrastructure is only used for freight purposes and that the air cargo center does not have to be relocated. Furthermore, a simple implementation of an automatic reloading of the containers between the cable car and the barge can be arranged.

The main limitation factors to this concept are the arising investment costs for the construction of the cable

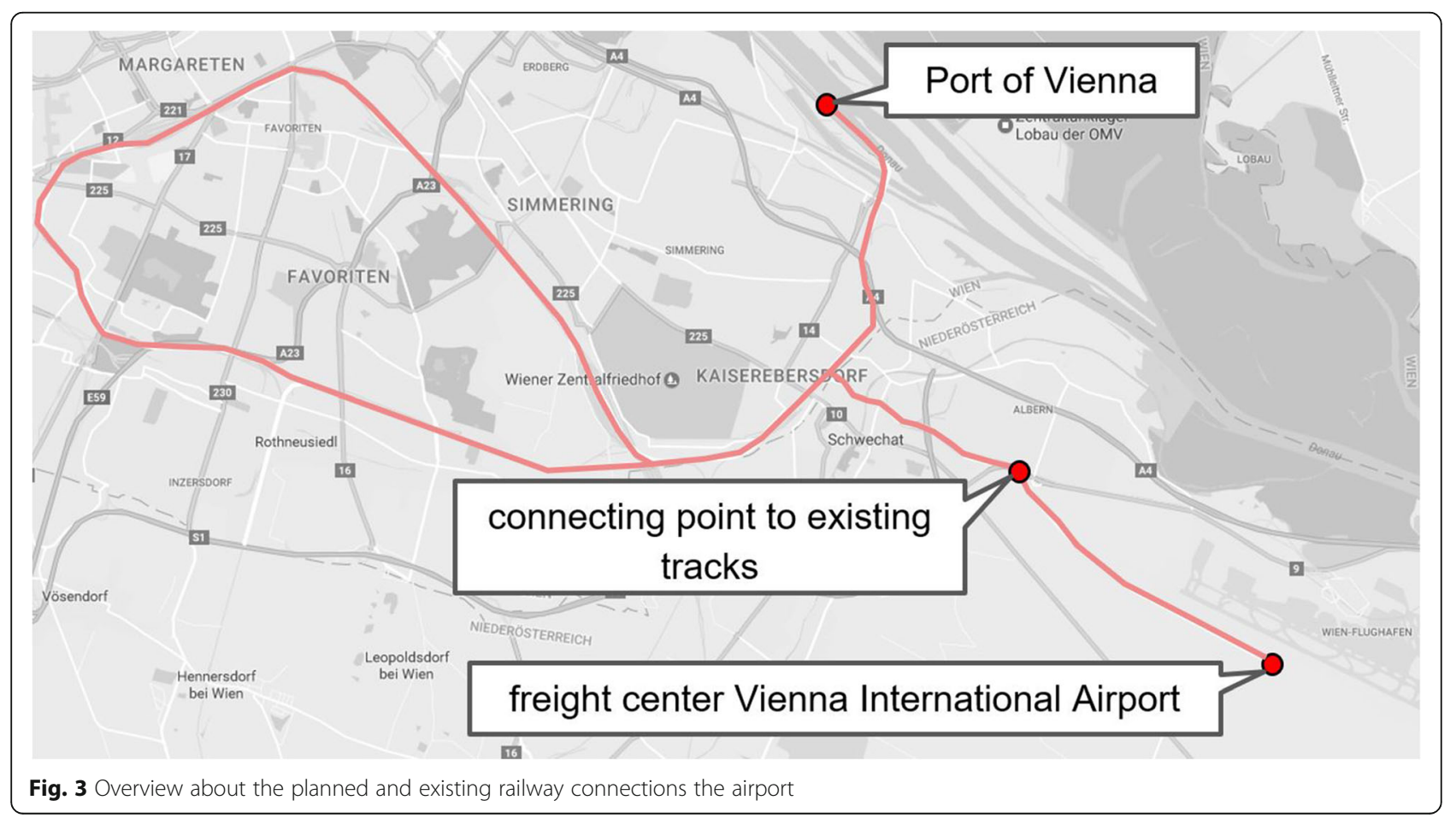




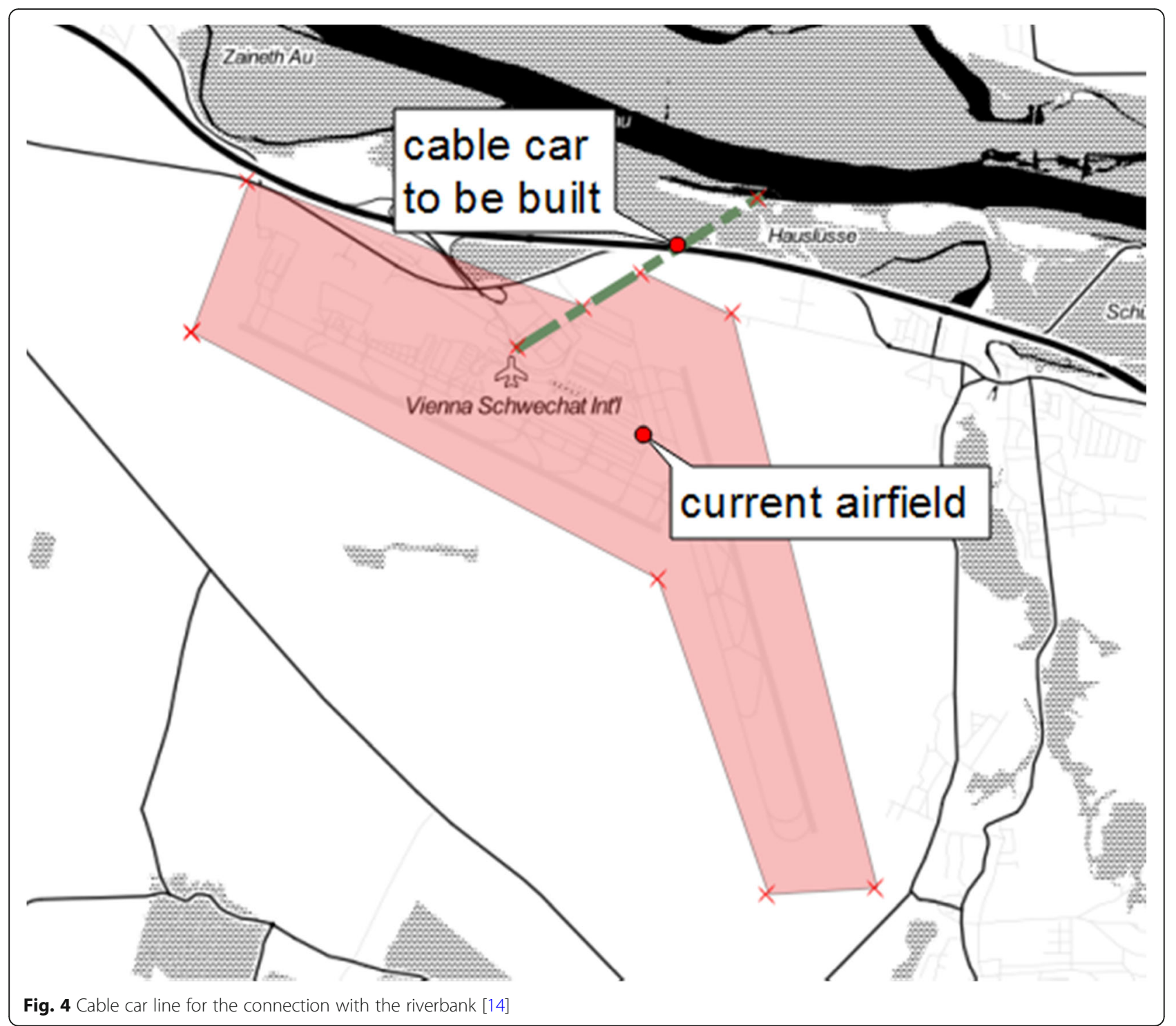

car as well as the territory of the national park which is affected. It cannot be predicted whether such a connection between airport and river is feasible in terms of environmental law as well as sites to be crossed (owned by railway and/or road operator) and what additional arising costs may accompany it.

\subsection{Connection via freight-zeppelin}

Despite the insolvency of the company Cargolifter in the year 2002, the concept of Zeppelins for transport purposes is not yet a thing of the past. Cargolux, a freight forwarder from Luxembourg, signed a strategic partnership with the aerospace company Aeros in the year 2015 to test the vertical removal of freight containers or large loads, which has been the main weakness of this means of transport [34].

An unconventional way to connect port and airport would be the introduction of a freight-airship [35, 36] which operates on its own tracks. The line could be for instance guided along the existing infrastructure (Fig. 1) using guiding ropes with a length of up to approximately $9.6 \mathrm{~km}$ and pillars of $20 \mathrm{~m}$ to $30 \mathrm{~m}$ height. Since standard solutions are currently not available on the market, the technical configuration can only rely on the solutions from the cable railway sector taking into account the unequal wind impact area of the freight-airship to the conventional gondolas which require to be picked up by special constructions in order to prevent the round rope from being pulled out.

The freight-airship would by far be the least space consuming and the quietest option to connect the port and the airport but there is no existing infrastructure and therefore costs including investment, ground rent and cost of operation arise. Additional requirements of owners of the sites to be crossed (especially the railway operator) should be taken into account since these are very likely to occur. 


\subsection{Impact on existing road network}

As mentioned in Chapter 4.1, the road link is the only existing connection between the airport and the port. To assess the impact of additional truck traffic on the road network, the effect on the travel time was investigated for the section concerned on the A4 Ost Autobahn (East Highway) for each direction.

The targeted road segment between the highway junctions "ASt Flughafen Schwechat" and "ASt Simmering" has a length of approximately $11 \mathrm{~km}$. In both directions a two-lane section between "ASt Simmering" and "ASt Schwechat" (link with the highway "S1") and a threelane section between "ASt Schwechat" and "ASt Flughafen Schwechat" is available (Fig. 5). Thus, the capacity of the two-lane section limits how much additional vehicles can use the entire route.

In terms of methodological approach, Volume Delay Functions (VDF) were used which express the travel time or travel time loss as a function of the traffic volume and therefore require a capacity value of the road traffic system as an input variable [36].

The fact that the capacitator value decreases with increasing interval duration has been described as a constant, for example, by Keller et al. [37] and Ponzlet [38]. A more recent study explains that the probability of congestion increases with increasing interval duration [39]. The investigation of Keller et al. [37] shows that a fundamental diagram based on 5-min intervals in the area of free and partial traffic represents a fundamental diagram valid for stationary states. However, a linear calculation of the ascertained capacitator value C5 from 5-min intervals to the maximum traffic volume per hour would exceed the capacity, which is why Keller et al. [37] derive a factor for determining the capacity from their empirical investigations. For the calculation of capacity C60 therefore applies:

$$
C_{60}=0,84 * C_{5} * 12
$$

To measure the influence of heavy traffic on traffic density, the traffic volume is calculated in passenger car units instead of vehicle traffic intensities.

$$
q_{P C E}=q_{P K W}+q_{L K W} * f_{L K W}
$$

$q_{P C E}$ Total traffic volume in passenger car units [passenger car units per hour]

$q_{P K W}$ Passenger car traffic density [passenger cars per hour]

\section{$q_{L K W}$ Truck traffic density [trucks per hour]}

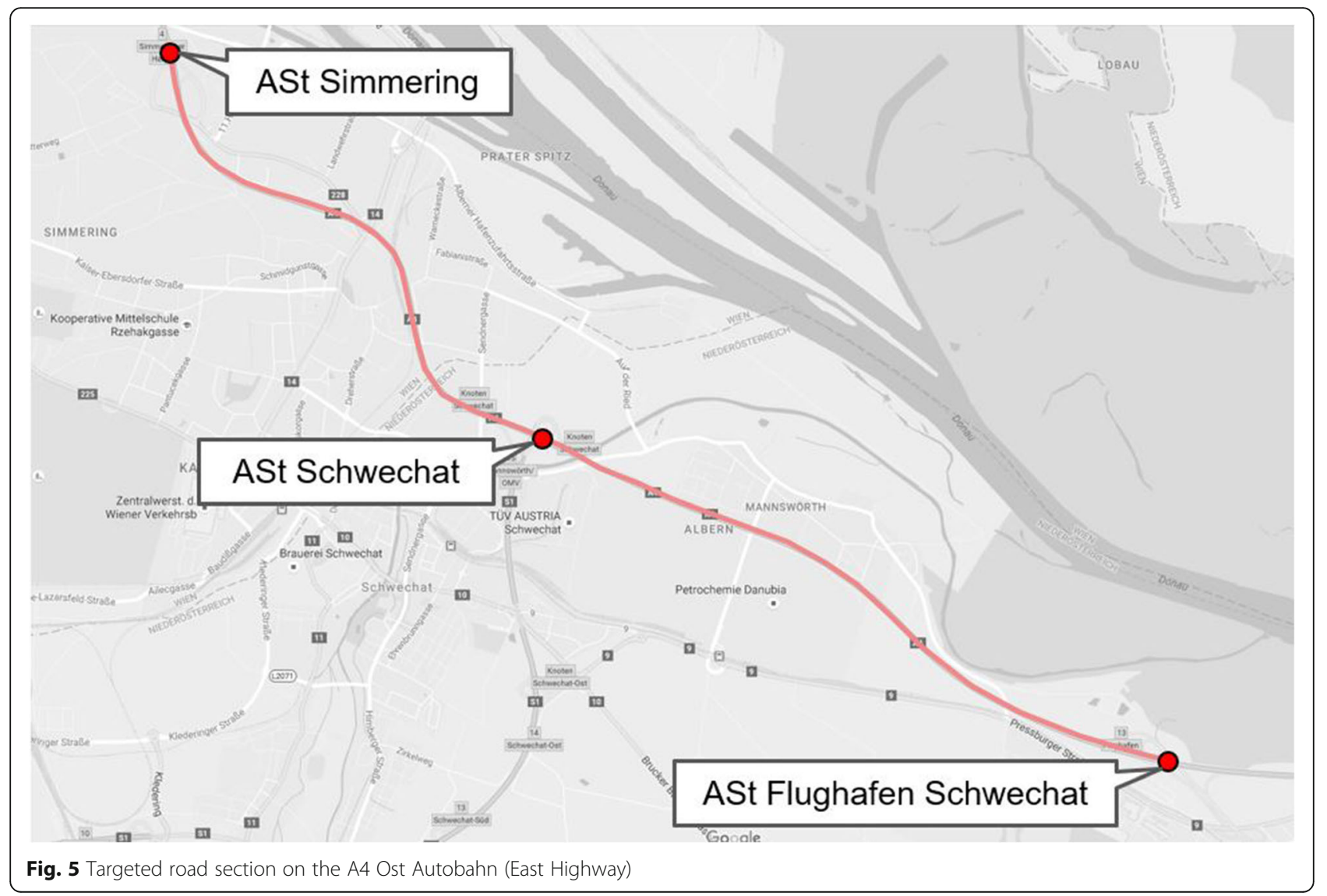


$f_{L K W}$ Conversion factor of truck traffic in passenger car units [-]

Geistefeldt [40] describes the influence of a truck on the occupancy rate of a four-lane section with two to three passenger car units (equivalent $\mathrm{f}_{\mathrm{SV}}$ for the conversion of the heavy traffic volume in passenger car units with a heavy traffic share of 5-15\%). Based on these findings, a factor of $\mathrm{f}_{\mathrm{LKW}}=2$ is assumed.

The speed at free traffic flow $v_{0}$ is a constant cross section specific value but must not be equated with the legally permissible speed. In this study, $\mathrm{v}_{0}$ is assumed to be a $95 \%$ quantile of all driven current speeds at the cross section. A representative of the conical VDF is the hyperbolic function according to Akcelik [41]:

$$
t_{a k t}=t_{0}+0,25 \cdot T\left(\frac{q_{P C E}}{C}-1+\sqrt{\left(\frac{q_{P C E}}{C}-1\right) 2+\frac{8 \cdot J_{D} \cdot \frac{q_{P C E}}{C}}{T \cdot C}}\right)
$$

$q_{P C E}$ Total traffic volume in passenger car units [passenger car units per hour]

CCapacity [passenger car units per hour]

TFlow period (Time interval in which a certain traffic volume $q$ prevails)

$J_{D}$ Delay parameter

The function parameters are estimated by a nonlinear regression analysis using a Least Square Method.

The capacity was calculated with an Aerde function [42] for all available cross sections in both directions on the highway A4 between the junction "ASt Prater" $(\mathrm{km} 0.0)$ and the Airport "ASt Flughafen Schwechat" (roughly at $\mathrm{km} \mathrm{12.5)}$ in the period from January to June 2012. Night hours between $8 \mathrm{pm}$ and $6 \mathrm{am}$ were not considered [36]. The results on capacity and parameter of the VDF are clearly dependent on the cross section or the type of the cross section. From the results of the REFEREE project [36] two cross sections of the highway A4 were selected, which had comparable characteristics to the route under consideration.

The following figure (Fig. 6) shows a v-k-diagram of the two-lane cross section "MQ_A04_2_003.200" in the direction of travel to Vienna, Fig. 7 for the three-lane cross section "MQ_A04_1_011.597" in the direction of travel to the Vienna International Airport near the junction "ASt Flughafen Schwechat".

The parameters free speed $v_{0}$, capacity $C$ and delay parameter $J_{D}$ of the two-lane highway section (MQ_A04_2_003.200) were the basis for the calculation of the VDF. As a basic load of the line segment, a typical time series of one working day of the year 2013 was selected on the respective route for one direction of travel (Fig. 8).

The calculated travel times for various additional loads $(+100$ to +1000 trucks per hour) show that the considered routes on highway A4 could take up additional journeys of trucks at certain times of the day, but at other times the capacity is significantly exceeded which means an additional travel time up to $10 \mathrm{~min}$ per road kilometer (Figs. 9 and 10). Especially during $4 \mathrm{pm}$ and $10 \mathrm{pm}$ both routes are already heavily used and can only accommodate a few additional trucks which means less than 300 trucks per hour.
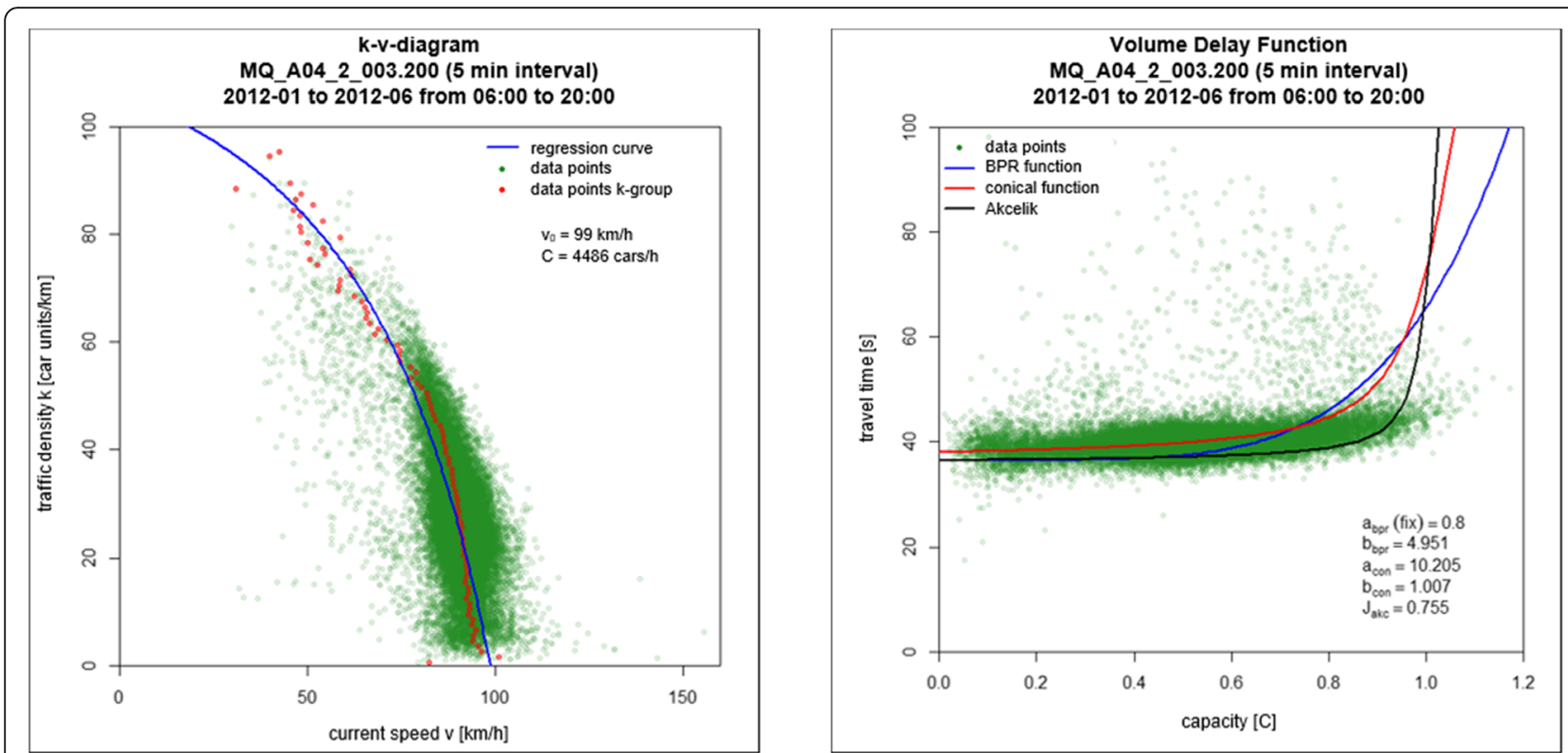

Fig. 6 k-v-diagram and Volume Delay function of the two-lane highway 

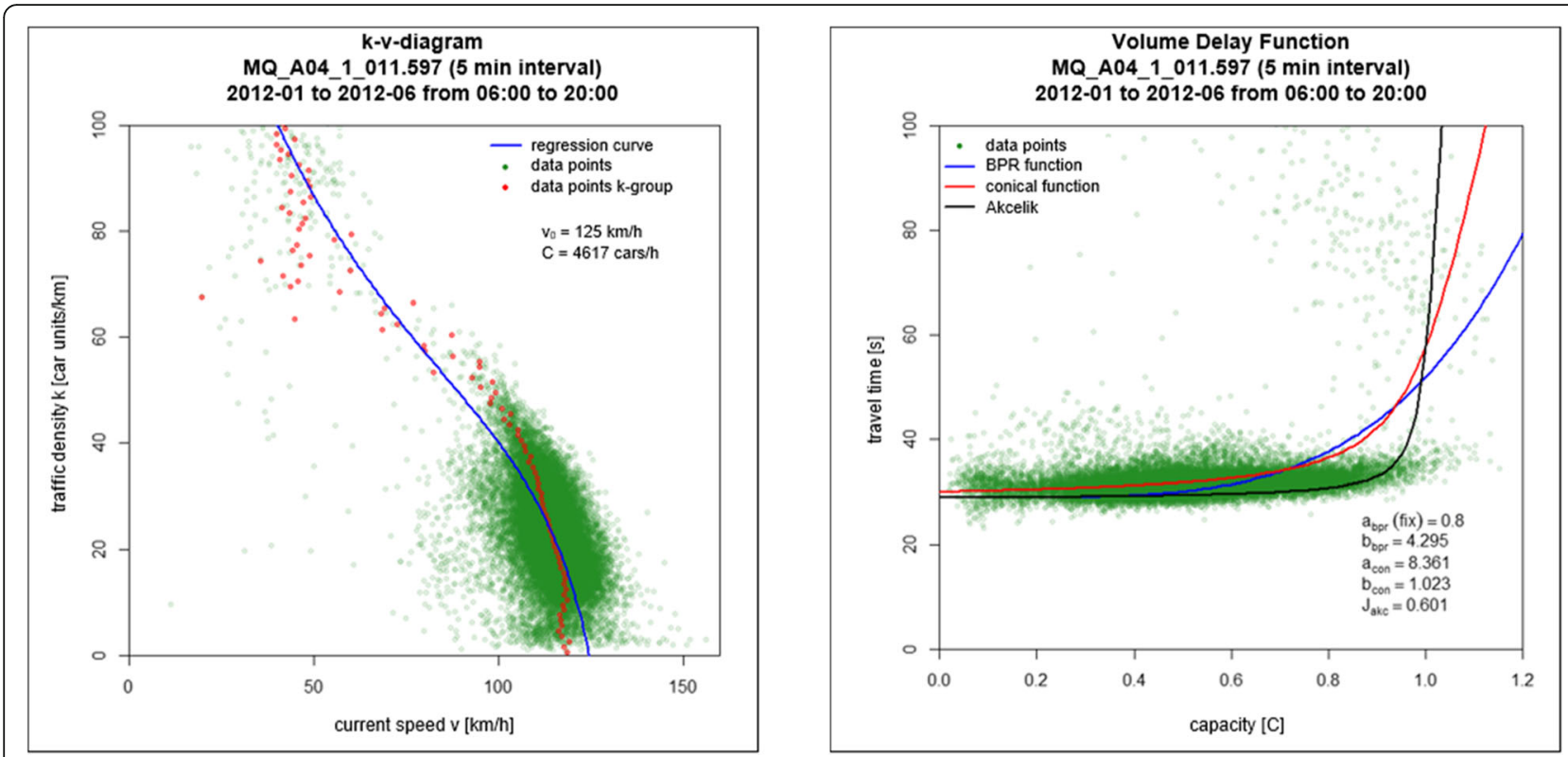

Fig. 7 k-v-diagram and Volume Delay function of the three-lane highway

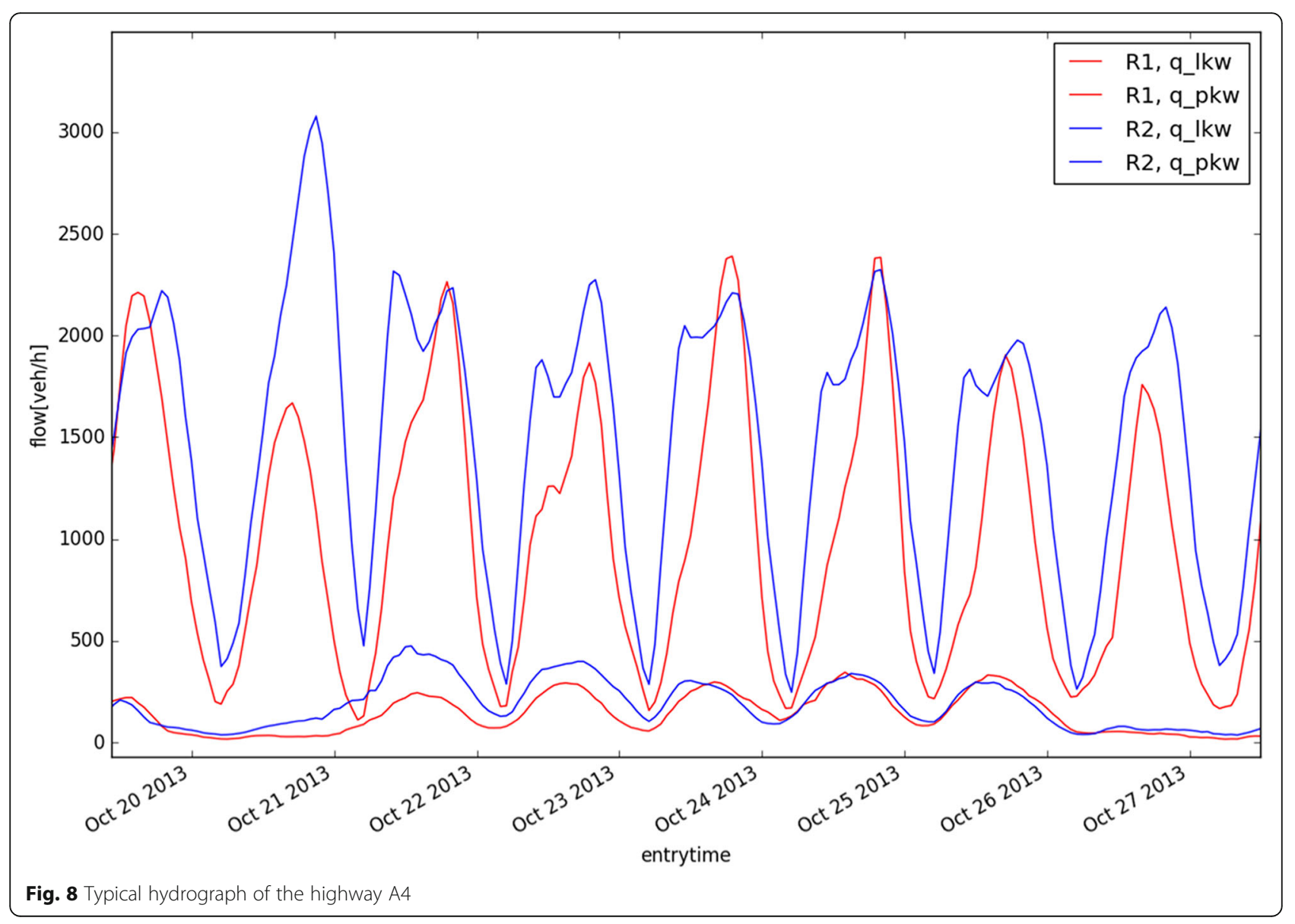


The results are rated for the measured values, in particular the hydrographs of the passenger car traffic intensity of the year 2013.

As a result of the travel time extensions determined, the attractiveness for the connection in motorized individual traffic (MIV) is reduced in the section between junction of the highway A4 at "ASt Simmeringer Haide" and "ASt Flughafen Schwechat".

According to a survey commissioned by the Planungsgemeinschaft Ost (planning association east), the relations between the districts of Vienna-region (east), Bruck/Leitha, Neusiedl and Eisenstadt as well as the neighboring countries of Slovakia and Hungary to and from Vienna are affected [43]. The reduction in the demand for transport on these relations which results from increased travel times is estimated with an elasticity approach. Several studies [44-46] indicate a mean elasticity with respect to the travel time in the MIV with -0.4 which means that a travel time increase of $10 \%$ is estimated to result in a decrease of traffic demand of MIV by $4 \%$ for this transport connection. According to the predicted travel times (Figs. 9 and 10) on the envisaged sections of the highway A4, some significant declines in MIV traffic could be expected as a result of the increase in truck traffic.

\subsection{Impact on existing rail network}

The presented approach to create a quattromodal freight hub by connecting the port of Vienna and the Airport of Vienna via rail in Chapter 4.2 requires usage of the existing rail network. Therefore, it is limited by the network capacity. To assess the feasibility of such a connection, the underlying assumptions are disclosed in the following section.

The developed scenario is represented by a new freight center situated in the south of the runway 11/34 (eastwest) and the existing railway connection to the airport train station. The freight center will be connected via new railway siding which should have its starting point west of the existing train station "Mannswörth Bahnhof" (Fig. 5). The length of this single-track connection will be about $4 \mathrm{~km}$. It opens at the freight center to three loading tracks and a bypass track with a dead-end track of about $200 \mathrm{~m}$ length to replace the locomotives for the retour journey.

The logistics concept includes the handling of the air freight to containers in the freight center for the transport of these goods to the harbor or for the longdistance transport of complete wagonloads. Regarding to the number of 300 trucks $(2 \times 20$ " or $1 \times 40$ " container $)$ mentioned in Chapter 4.5 and based on the capacity of a

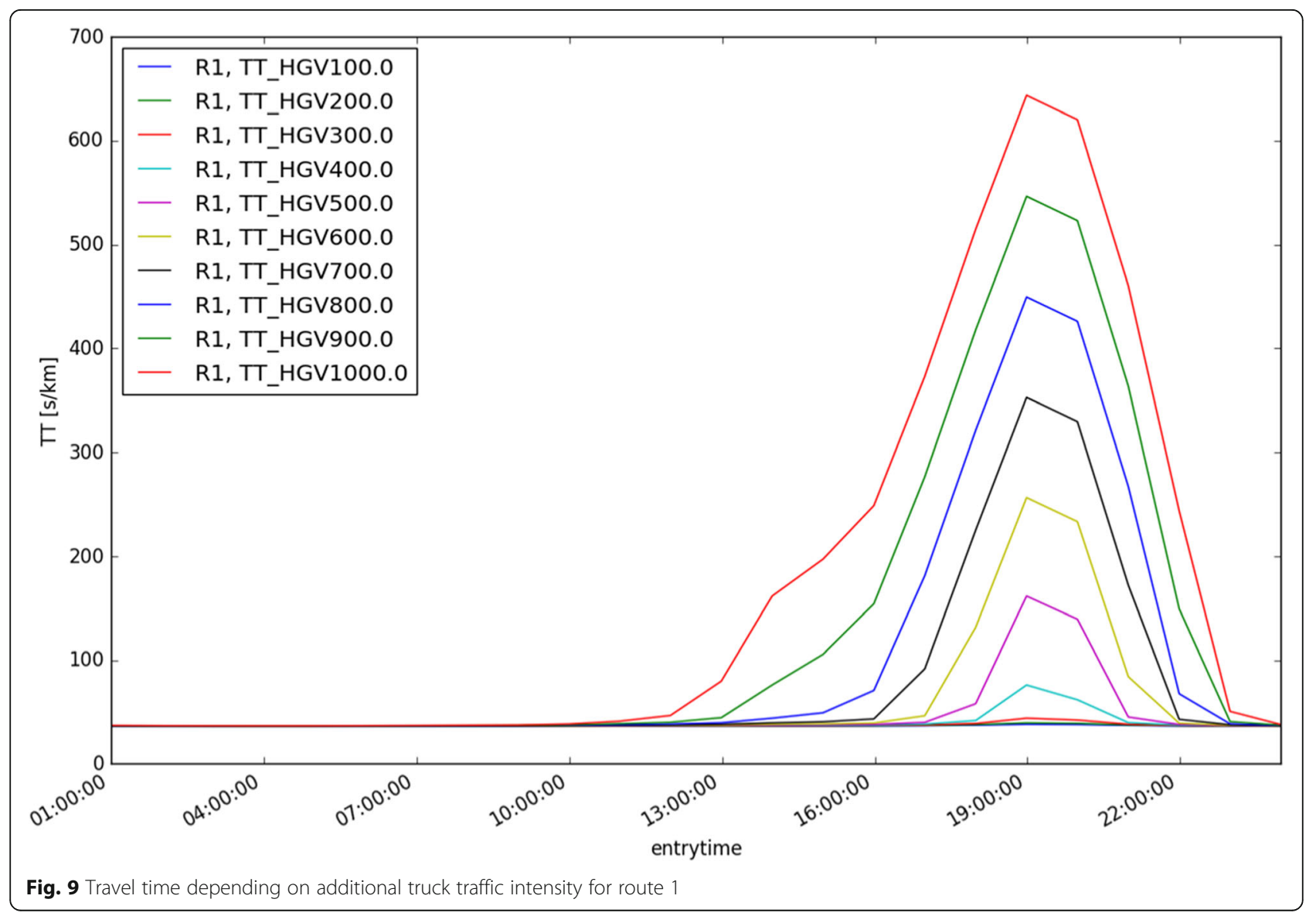




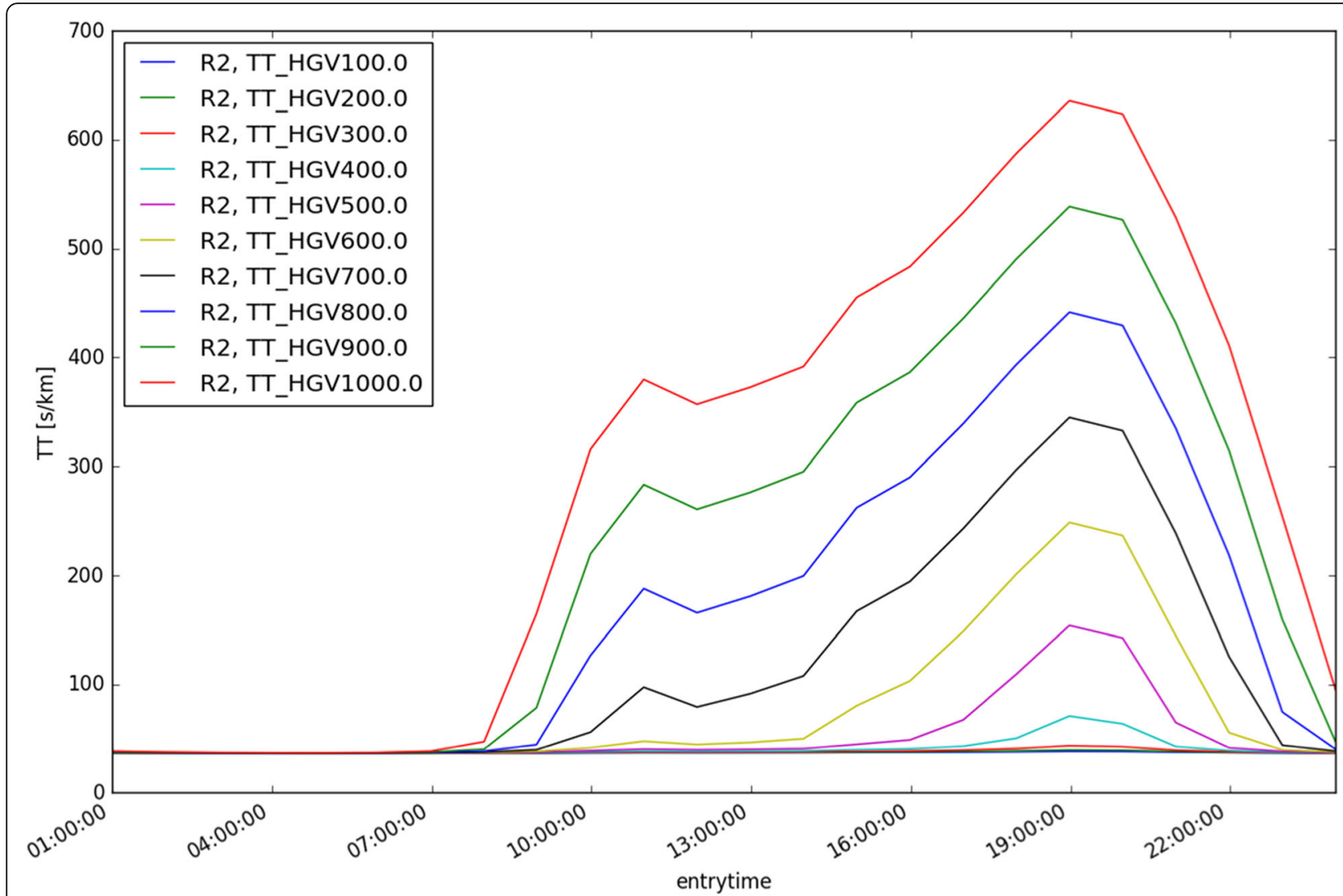

Fig. 10 Travel time depending on additional truck traffic intensity for route 2

typical container rail freight wagon type "Sgnss" $(3 \times 20$ " containers or $1 \times 40^{\prime \prime}$ and $\left.1 \times 20^{\prime \prime}\right)$ it is expected that about 13 to14 short trains $(300 \mathrm{~m})$ will run in both directions each day.

The logistics concept foresees the transfer of the freight wagons to the central shunting yard in "Kledering" to shunt the wagons dedicated to the harbor and to other destinations. This approach has the advantage that the freight wagons can be separated and transferred to the harbor without shunting activities in the small train station of "Wien Kaiserebersdorf".

The current time table of the railway connection between the City of Vienna and the airport shows about 7 to 9 trains in each direction depending to the day time and some freight trains heading to the refinery at Schwechat. The operations capacity of the railway line between station "Mannswörth Bahnhof" and "Wien Kaiserebersdorf" shows enough potential to manage the additional trains in both directions.

\section{Conclusions and outlook}

This paper describes the concept of quattromodality from a theoretical and practical point of view, covering not only the definition and details on spatial, technological and organizational aspects as well as arising potentials but also offering implementation concepts for the City of Vienna.

To investigate the mentioned aspects of quattromodal freight hubs designating "logistic pivots where the four MOT road, rail, waterways and air cargo come together" [16]. stakeholder interviews and site visits were performed. In many discussions, it was often mentioned that the combination of air cargo and inland navigation is not meaningful. However, the main advantage of a quattromodal freight hub is not the ability to transship directly from plan to vessel (although this is also done for specific freight groups as outlined by the interviewees during the Hamburg site visit) but the savings potential due to synergies. E.g., instead of having to implement customs treatment at two locations, one combined treatment can be employed. To get one step further than assessing the concept itself and the current situation at two important logistic hubs, the spatial implementation for the City of Vienna was analyzed.

The investigation of quattromodal freight hubs has revealed the strengths and opportunities offered by combining four different MOT but also the weaknesses and risks that should be envisaged before implementing. The experts' opinions unfold cost and efficiency related 
decision criteria as most important and (not surprisingly) do not focus on environmental aspects too much. Apart from that, it is agreed with the positive aspect on the prestige of a region and hence on the USP of a site. This would indeed be beneficial for the City of Vienna which is already an important hub within Europe and could strengthen its position by offering this flexible and cost-efficient approach of selecting the most appropriate MOT out of the four offered ones.

A further investigation of an implementation in the City of Vienna revealed four different options to connect the port of Vienna (trimodal hub) with the Vienna International Airport (bimodal hub). Each of them offers certain advantages but also leads to challenges since the implementation does not happen on a brownfield but within a well elaborated transport network and a city structure characterized by high building density as well as strong legal regulations.

This also indicates the shortcoming in the research when it comes to legal aspects of an implementation of new infrastructure elements in the existing network. While the effect of a connection on the existing transport network was assessed, the legal implications could only be noted and not be solved on a theoretical basis so far. Since land holding might be involved and these legal questions cannot be answered generally.

Another factor that might be worth considering is the effect on the region by offering faster transport channels. More efficiency in freight transport does offer potential for additional loads and most probably connects the region much stronger. Although technological developments are already taking place and the already mentioned concepts emerge as promising alternatives (e.g. high-speed transport and efficient maritime links), its effect on network quality and thus on the flows of goods and persons and the affected regions (fusion of agglomerations) is currently not a major concern at the European level.

\section{Additional files}

Additional file 1: Questionnaire. (DOCX $18 \mathrm{~kb}$ )

Additional file 2: Interview Guide. (DOCX $31 \mathrm{~kb}$ )

\section{Acknowledgements}

We thankfully acknowledge the time and expertise provided by the stakeholders and experts during our site visits and interviews. This work has been partially funded by the Austrian Federal Ministry for Transport, Innovation and Technology (bmvit) in the 'Mobilitaet der Zukunft' program under grant number 850339 ("Q4").

\section{Authors' contributions}

KM participated in the Hamburg site visit, carried out interviews with stakeholders and worked on the application for the city of Vienna. KM and MP are responsible for the conceptualization, original draft preparation, review and editing. MP carried out interviews with stakeholders and worked on the application for the city of Vienna as well as on the visualizations. JZ worked on technical details of the application for the city of Vienna as well as the validation. $\mathrm{BH}$ and $\mathrm{GL}$ measured the impact on the existing road network in Vienna. GH was responsible for the funding acquisition and supervision. He contributed to the methodology and gave feedback on the work performed. MW and CB worked on the project administration, participated in the Hamburg site visit, carried out interviews with stakeholders and did research on the gaps in knowledge with regard to the integration of the air freight to quattromodal freight hub. SP organized and participated in the Hamburg site visit, carried out part of the desk research and performed interviews with stakeholders. OS and LP carried out part of the desk research. RS and SE participated in the Constanta site visit, carried out interviews with stakeholders, performed the potential assessment and SWOT analysis and gave feedback to the other tasks performed. All authors read and approved the final manuscript.

\section{Competing interests}

The authors declare that they have no competing interests.

\section{Author details}

${ }^{1}$ AIT Austrian Institute of Technology, Center for Mobility Systems, Giefinggasse 4, 1210 Vienna, Austria. ${ }^{2}$ Vienna University of Technology, Augasse 2-6, 1090 Vienna, Austria. ${ }^{3}$ University of Applied Sciences Upper Austria, LOGISTIKUM Steyr, Wehrgrabengasse 1, Steyr, Austria. ${ }^{4}$ University of Applied Sciences BFI Vienna, Wohlmutstrasse 22, 1020 Vienna, Austria.

Received: 22 March 2018 Accepted: 8 May 2019

Published online: 01 July 2019

\section{References}

1. European Comission (2016) 2020 climate \& energy package. http://ec. europa.eu/clima/policies/strategies/2020/documentation_en.htm. Retrieved on: 11/11/2016

2. United Nations Climate Change (2018) What is the Paris agreement? https:// unfccc.int/process-and-meetings/the-paris-agreement/what-is-the-parisagreement. Retrieved on: 17/12/2018

3. United Nations Climate Change (2018) Katowice climate change conference - December 2018. https://unfccc.int/katowice. Retrieved on: 17/12/2018.

4. European Commission (2011) White paper on transport. Roadmap to a single European transport area - Towards a competitive and resourceefficient transport system. http://ec.europa.eu/transport/sites/transport/files/ themes/strategies/doc/2011_white_paper/white-paper-illustrated-brochure_ en.pdf. Retrieved on: 11/11/2016.

5. Montreuil, B. (2011). Towards a physical internet: Meeting the global logistics sustainability grand challenge. Logistics Research., 3(2-3), 71-87.

6. Ballot, E., Montreuil, B., \& Meller, R. D. (2014). In Predit (Ed.), The physical internet. Paris: La Documentation Francaise.

7. Lucassen, I., \& Dogger, T. (2012). Synchromodality pilot study. In Identification of bottlenecks and possibilities for a network between Rotterdam, Moerdijk and Tilburg. Delft: TNO.

8. ALICE (2014) Corridors, hubs and Synchromodality research innovation roadmap. http://www.etp-logistics.eu/alice/en/publications/. Retrieved on: 14/4/2017.

9. Pfoser, S., \& Treiblmaier, H. (2016). Schauer O (2016) critical success factors of Synchromodality: Results from a case study and literature review. Transportation Research Procedia, 14(1), 1463-1471.

10. Gregori, G., \& Wimmer, T. (2011). Grünbuch der nachhaltigen Logistik. In Handbuch für die ressourcenschonende Gestaltung logistischer Prozesse. Vienna: Eigenverlag Bundesvereinigung Logistik Österreich.

11. BVL. (2014). Grünbuch - Nachhaltige Logistik in urbanen Räumen. Vienna: Eigenverlag Bundesvereinigung Logistik Österreich.

12. IATA (2015) IATA air passenger forecast shows dip in long-term demand. Total passangers set to double to 7 billion by 2034. http://www.iata.org/ pressroom/pr/Pages/2015-11-26-01.aspx. Retrieved on: 11/11/2016.

13. Rondinelli, D., \& Berry, M. (2000). Multimodal transportation, logistics, and the environment: Managing interactions in a global economy. European Management Journal, 18(4), 389-410.

14. Zhang, A., Lang, C., Hui, Y. V., \& Leung, L. (2007). Intermodal alliance and rivalry of transport chains: The air cargo market. Transport Research Part E: Logistics and Transportation Review, 17, 234-246. 
15. Kummer, S. (2008). Leistungsprofil und geeignete Transportgüter für ein quatromodales (Breitspur-Normalpur-Binnenschiff-Straße) Terminal im Raum Wien-Bratislava. Vienna: Institut für Transportwirtschaft und Logistik, WU.

16. Prandtstetter, M., Markvica, K., Zajicek, J., Pfoser, S., Schauer, O., Putz, L., Hauger, G., Wanjek, M., Berkowitsch, C., Schodl, R., \& Eitler, S. (2016). Integrating air cargo into multimodal transportation networks: Vision and practical relevance of quattro-modal freight hubs. In Proceedings of the European transport conference 2016 (pp. 14-28).

17. Hauger, G., Wanjek, M., Berkowitsch, C., Pfoser, S., Schauer, O., Putz, L., Schodl, R., Eitler, S., Prandtstetter, M., \& Markvica, K. (2016). Concept of Quattro modal freight hubs. Proceedings Engineering, 161, 2121-2126.

18. Berkowitsch, C., Breinbauer, A., Eitler, S., Ennser, B., Hauger, G., Heilmann, B., Lenz, G., Markvica, K., Nagler, M., Pfoser, S., Prandtstetter, M., Putz, L., Schauer, O., Schodl, R., Wanjek, M., \& Zajicek, J. (2016). Quattromodale Knoten: Forschungs- und Praxisrelevanz für den Güterverkehr. In G. Hauger (Ed.), IVSSchriften (Vol. 40, pp. 1-130). Vienna: TU-Verlag ISBN: 978-3-903024-36-6.

19. hamburg.de (2018) Fakten \& Zahlen. Hamburg in Zahlen. https://www. hamburg.de/info/3277402/hamburg-in-zahlen/. Retrieved on: 31/10/2018.

20. Statistisches Amt für Hamburg und Schleswig-Holstein (2018): Monatszahlen - Bevölkerung. https://www.statistik-nord.de/daten/bevoelkerung-undgebiet/monatszahlen-4/. Retrieved on: 31/10/2018.

21. Handelskammer Hamburg. (2010). Branchenporträts. Güterverkehr in Hamburg. Drehscheibe Nordeuropa. Hamburg: Handelskammer Hamburg.

22. Hamburg Airport (2018) Geschäftsbericht 2017. https://www.hamburgairport.de/media/180314_GB2017 web.pdf. Retrieved on: 31/10/2018.

23. Port of Hamburg (2018) Port of Hamburg handling figures. https://www. hafen-hamburg.de/en/statistics. Retrieved on: 31/10/2018.

24. Romania - Natural and Cultural (2018) Constanta (Kohn stahn' tsah). http:// romaniatourism.com/constanta.html. Retrieved on: 5/11/2018.

25. Maritime Ports Administration S.A. Constanta (2018) Annual Report 2017 Port of Constanta. http://www.portofconstantza.com/apmc/i.do?lan=en. Retrieved on: 6/11/2018.

26. City of Constanta (2018) Exporeal 2018. http://rumaenien.ahk.de/fileadmin/ ahk_rumaenien/Bilder/2018/EXPO_REAL_18/new/CONSTANTA.pdf. Retrieved on: $6 / 11 / 2018$

27. RailFreight.com (2017) Logistic services on Poland-Romanian corridor to improve. https://www.railfreight.com/business/2017/08/02/logistic-serviceson-poland-romanian-corridor-to-improve/. Retrieved on: 6/11/2018.

28. Nine O' Clock (2014) IATA promotes freight terminal al Mihal Kogalniceanu international airport. https://www.nineoclock.ro/2014/10/ 02/iata-promotes-freight-terminal-al-mihal-kogalniceanu-internationalairport/. Retrieved on: 6/11/2018.

29. Kanatschnig, D., \& Mandl, S. (2015). Smart Rebound. Steigerung der Energieund Ressourceneffizienz durch Rebound-Prävention bei Smart Cities. Berichte aus Energie- und Umweltforschung 35/2015. Vienna: bm:vit.

30. ABA (2014) Logistik-Standort Österreich. http://investinaustria.at/de/ infomaterial/broschueren/logistik-oesterreich.pdf. Retrieved on: 26/9/2016.

31. Advantage Austria WKÖ (2016) Transport und Logistik - Zahlen und Fakten. https://www.advantageaustria.org/de/zentral/business-guide-oesterreich/ importieren-aus-oesterreich/logistik/zahlen-und-fakten.de.html. Retrieved on: 26/9/2016.

32. Flughafen Wien (2011). (n.d.). Zukunft Flughafen Wien 3. Vienna: Piste. Flughafen Wien AG. https://www.viennaairport.com/jart/prj3/va/uploads/ data-uploads/Konzern/projektinfo_piste3_de.pdf.

33. De Decker, K. (2011). Aerial ropeways: Automatic cargo transport for a bargain. In Low-tech magazine, online-source 26/1/2011, Barcelona Retrieved on: $26 / 9 / 2016$

34. Hegmann, G. (2013). Neuer Anlauf für Riesen-Fracht-Zeppeline in Europa. In Welt N24 https://www.welt.de/wirtschaft/article122931303/Neuer-Anlauffuer-Riesen-Fracht-Zeppeline-in-Europa.html. Retrieved on: 20/9/2016.

35. Baker, B. (2014). Commercial crossover makes Aeroscraft military airship dream come true. In Army-technology.Com, online-source 21/11/2014, London Retrieved on: 26/ 9/2016.

36. Aleksa, M., Epp, T., Heilmann, B., Neuhold, R., Sidla, O., Pohl, F., \& Ponweiser, W. (2013). Ergebnisbericht Projekt REFEREE (Referenzierung und Evaluierung von verkehrstechnischen Effekten). Funding programm iv2splus (831730), Vienna.

37. Keller, H., \& Sachse, T. (1992). Einfluss des Bezugsintervalls in Fundamentaldiagrammen auf die zutreffende Beschreibung der Leistungsfähigkeit von Straßenabschnitten. In Schriftenreihe Forschung Straßenbau und Straßenverkehrstechnik (Vol. 614). Bonn: Bundesminister für Verkehr, Abt. Straßenbau.
38. Ponzlet, M. (1996). Dynamik der Leistungsfähigkeiten von Autobahnen, Auswirkungen von systematischen und umfeldbedingten Schwankungen des Geschwindigkeitsverhaltens und deren Beschreibung in Verkehrsflussmodellen. Bochum: Schriftenreihe des Lehrstuhls für Verkehrswesen der RuhrUniversität Bochum.

39. Brilon, W., Geistefeldt, J., \& Regler, M. (2005). Reliability of freeway traffic flow: A stochastic concept of capacity. In Proceedings of the 16th international symposium on transportation and traffic theory (Vol. 347, pp. 125-144).

40. Geistefeldt, J. (2007). Verkehrsablauf und Verkehrssicherheit auf Autobahnen mit vierstreifigen Richtungsfahrbahnen. In Schriftenreihe des Lehrstuhls für Verkehrswesen der Ruhr-Universität Bochum (Vol. 30). Bochum: Lehrstuhl für Verkehrswesen - Planung und Management.

41. Akcelik, R. (1991). Travel time functions for transport planning purposes: Davidson's function, its time-dependent form and an alternative travel time function. Australian Road Research, 21(3), 49-59.

42. van Aerde, M. (1995). A single regime speed-flow-density relationship for freeways and arterials. In Proceedings of the 74th TRB annual meeting.

43. Rittler, C. (2011). Kordonerhebung Wien in den Jahren 2008 bis 2010, im Auftrag der Planungsgemeinschaft Ost (PGO), Vienna.

44. Prognos, A. G. (2000). Sensitivitäten von Angebots- und Preisänderungen im Personenverkehr. Forschungsauftrag 44/99 auf Antrag der SVI, Vienna.

45. ETH. (2012). Übersicht zu Stated Preference-Studien in der Schweiz und Abschätzung von Gesamtelastizitäten - Statusbericht 2012. Zürich: Institut für Verkehrsplanung und Transportsysteme, ETH Zürich.

46. TNS (2014) Ermittlung von Bewertungsansätzen für Reisezeiten und Zuverlässigkeit auf der Basis eines Modells für modale Verlagerungen im nicht-gewerblichen und gewerblichen Personenverkehr für die Bundesverkehrswegeplanung. FE-Projekt-Nr. 96.996/2011.

\section{Publisher's Note}

Springer Nature remains neutral with regard to jurisdictional claims in published maps and institutional affiliations.

\section{Submit your manuscript to a SpringerOpen ${ }^{\circ}$ journal and benefit from:}

- Convenient online submission

Rigorous peer review

- Open access: articles freely available online

- High visibility within the field

- Retaining the copyright to your article

Submit your next manuscript at $\boldsymbol{\nabla}$ springeropen.com 